\title{
Aplikasi Reservasi Penginapan berbasis Android
}

\author{
Budhi Sumboro*1, Widyo Ari Utomo ${ }^{2}$, Agung Koes Indarto ${ }^{3}$, Deas Eka Saputra ${ }^{4}$ \\ ${ }^{1,4}$ Program Studi Sistem Informasi, STMIK AUB, Surakarta, Indonesia \\ ${ }^{2,3}$ Program Studi Sistem Komputer, STMIK AUB, Surakarta, Indonesia \\ e-mail: *1budhi.sumboro@stmik-aub.ac.id, ${ }^{2}$ widyoari@stmik-aub.ac.id, ${ }^{3}$ aindarto@stmik- \\ aub.ac.id, ${ }^{4} 2167100881 @$ student.stmik-aub.ac.id
}

\begin{abstract}
Abstrak
Tawangmangu adalah salah satu destinsasi wisata yang popular di daerah Kabupaten Karanganyar. Banyak wisatawan yang pergi ke Tawangangu untuk bewisata menikmati alam maupun berwisata kuliner khas disana. Semakin banyak wisatawan membuat banyak pengelola penginapan bersaing untuk menarik minat pelanggan. Namun sedikitnya media promosi dan informasi yang bisa diakses oleh pelanggan, banyak pelanggan yang bingung dalam memilih penginapan yang sesuai dengan keinginan mereka. Untuk permasalahan tersebut maka menjadi penting pada penelitian ini dibuat aplikasi pemesanan yang bertujuan untuk dapat mempermudah proses reservasi penginapan di Pondok Wisata Saraswati dan mempermudah proses dokumentasi setiap transaksi yang terjadi. Sistem yang dibangun berbasis mobile sehingga memungkinkan pengelola melakukan transaksi secara daring tanpa harus bertatap muka. Pemesanan dan pembayaran dilakukan dengan menggunakan payment gateway. Hasil dari penelitian ini adalah sebuah sistem yang dapat membantu menyelesaikan masalah bagi perusahaan Pondok Wisata Saraswati.
\end{abstract}

Kata kunci-Tawangmangu, Pemesanan, Penginapan, Aplikasi Mobile

\begin{abstract}
Tawangmangu is one of the most popular tourist destinations in Karanganyar Regency. Many tourists go to Tawangangu to enjoy nature tours and special culinary tours there. More and more tourists make many inn managers compete to attract customers. However, at the lack of promotional media and information that can be accessed by customers, many customers are confused about choosing accommodation according to their wishes. For this problem, it becomes important in this study to create a booking application that aims to simplify the lodging reservation process at the Saraswati Tourism Cottage and simplify the documentation process for every transaction that occurs. The system is built on a mobile basis so that it allows managers to make transactions online without having to meet face to face. Orders and payments are made using a payment gateway. The result of this research is a system that can help solve problems for the company Pondok Wisata Saraswati.
\end{abstract}

Keywords - Tawangmangu, Reservations, Lodging, Mobile Applications

\section{PENDAHULUAN}

Pariwisata adalah suatu proses kepergian sementara dari sesorang atau lebih menuju tepat lain di luar tepat tinggalnya Dorongan kepergiannya adalah karena berbagai kepentingan, baik karena kepentingan ekonomi, sosial, kebudayaan, politik, agama, kesehatan maupun kepentingan lain seperti karena sekedar ingin tahu, menambah pengalaman ataupun belajar [22]. 
Tawangmangu adalah salah satu destinasi wisata yang ada di Kabupaten Karanganyar. Banyak wisatawan baik dari lokal maupun luar kota yang melancong ke Tawangmangu untuk menimati keindahan alam dan sekedar berwisata kuliner. Semakin banyaknya wisatawan yang dating, maka peluang usaha di daerah Tawangmangu pun semakin besar. Salah satunya adalah jasa penginapan.

Bisnis penginapan sangat menjanjikan karena seiring berkembangnya pariwisata diindonesia, maka akan semakin banyak pula wisatawan yang akan datang ke wilayah tersebut baik dari wisatawan lokal maupun manca negara. Maka secara tidak langsung akan mendorong potensi bisnis disekitar daerah wisata tersebut baik dari bidang kuliner, penjualan souvenir dan oleh - oleh, penyedia jasa akomadasi termasuk pula hotel dan penginapan salah satunya adalah Pondok Wisata Saraswati.

Sistem pemesanan kamar di Pondok Wisata Saraswati adalah datang langsung ke lokasi dan bertemu langsung dengan pengelola untuk mengetahui apakah ada kamar kosong yang bias digunakan atau tidak. Selain itu ada juga plang di jalur utama tawangmangu dan bisa menghubungi pengelola lewat aplikasi whatsapp.

Hal ini menjadi masalah jika calon pelanggan yang baru pertama kali memerlukan penginapan akan mencari lokasi dan informasi mengenai penginapan tersebut. Karena jika posisi pengelola penginapan sedang tidak standby aplikasi whatsapp, otomatis kita harus datang langsung dan mencari lokasi penginapan tersebut melaluui plang di pinggir jalan. Serta harus mengecek lagi kondisi lingkungan, kamar, dan tarif yang harus dibayarkan. dan apabila kita kurang cocok dengan beberapa faktor tersebut, otomatis calon pelanggan harus mencari lagi dengan metode yang sama sampai bertemu dengan penginapan yang diinginkan.

Berdasarkan latar belakang masalah yang terdapat di Pondok Wisata Saraswati, maka penulis merancang dan membuat sistem berbasis android untuk dapat mempermudah proses pemesanan penginapan, pengelola bisa mendata dengan rapi daftar tamu yang meninap, transaksi bisa dilakukan tanpa harus bertemu langsung dengan pengelola dan bisa dilakukan dengan metode pembayaran payment gateway beberapa hari sebelum check in.

\section{METODE PENELITIAN}

\subsection{Metode Observasi}

Dalam observasi peneliti terlibat dengan kegiatan sehari-hari orang yang sedang diamati atau yang digunakan sebagai sumber data penelitian [20]. Penulis melakukan observasi dengan mengamati secara langsung proses pemasaran, proses pemesanan, proses pembayaran, di Pondok Wisata Saraswati.

\subsection{Metode Wawancara}

Wawancara digunakan sebagai teknik pengumpulan data apabila peneliti ingin melakukan studi pendahuluan untuk menemukan permasalahan yang harus diteliti, tetapi juga apabila peneliti ingin mengetahui hal-hal dari responden yang lebih mendalam [20]. Penulis melakukan wawancara dengan pemilik Pondok Wisata Saraswati tentang bagaimana lingkungan penginapan, berapa jumlah kamar, servis apa saja yang diberikan, berapa tarif mengingap baik dalam waktu singkat atau lama, bagaimana prosedur pemesanan kamar.

\subsection{Metode Pustaka}

Studi kepustakaan berkaitan dengan kajian teoritis dan referensi lain yang terkait dengan nilai, budaya, dan norma yang berkembang pada situasi sosial yang diteliti. Dan ada tiga kriteria yang terkait teori yang digunakan sebagai landasan penelitian, yaitu relevansi, kemutakhiran dan keaslian [20]. Penulis mencari informasi dari internet, dari perpustakaan, dari buku dan jurnal sebagai bahan referensi sebagai acuan dalam penulisan laporan dan juga pembuatan software aplikasi ini. 


\subsection{Analisis Sistem}

Untuk menganalisa kelemahan sistem diperlukan langkah untuk mengidentifikasi dan memberikan solusi terhadap kelemahan sistem yang ada, maka sebagai landasan penulis menggunakan metode atau kerangka PIECES yang terdiri dari performance, information, economy, control, efficiency dan service. Analisa ini digunakan sebagai alat ukur untuk menentukan sistem baru layak atau tidak, karena enam aspek ini harus mengalami peningkatan ukuran yang lebih baik dari sistem lama agar dapat mendukung proses transaksi.

a. Performance (Analisa Kinerja Sistem)

Waktu yang dibutuhkan untuk mencatat jumlah tamu, pengeluaran untuk makanan dan minuman, listrik, gas dll masih menggunakan catatan manual dibuku. Sehingga untuk melihat daftar pengeluaran bulanan perlu membaca data dari buku catatan sehingga kurang efisien dan memerlukan waktu untuk mendata pengeluaran bulanan.

b. information (Analisa Informasi)

Informasi mengenai ketersediaan dan tarif penginapan di Pondok Wisata Saraswati sangat terbatas dan butuh waktu karena harus datang langsung ke penginapan atau melalui whatsapp tetapi harus menunggu respon dari pemilik penginapan.

c. Economy (Analisis Ekonomi)

Penjual mencatat stok dan transaksi penjualan di buku, dilihat untuk jangka panjangnya biaya untuk pengadaan alat tulis dan buku semakin meningkat seiring dengan perkembangan usaha dan kebutuhan alat tulis dan pelanggan juga harus datang ke Pondok Wisata Saraswati yang mana harus membutuhkan waktu dan biaya.

d. Control (Analisis Pengendalian)

Pada sistem yang sedang berjalan keamanan data sangat kurang, data penting seperti nota-nota pemesanan tidak aman karena bisa hilang atau rusak.

e. Efficiency (Analisis Efisiensi)

Dalam proses pencatatan spesifikasi barang dan pembayaran lama karena menggunakan nota kertas yang ditulis tangan oleh pemilik.

f. Service (Analisis Pelayanan)

Dalam proses transaksi terhitung lama, karena harus mengecek dahulu kamar yang tersedia dan dalam proses pembayaran apabila tidak membawa uang tunai otomatis tidak bisa melakukan transaksi. 


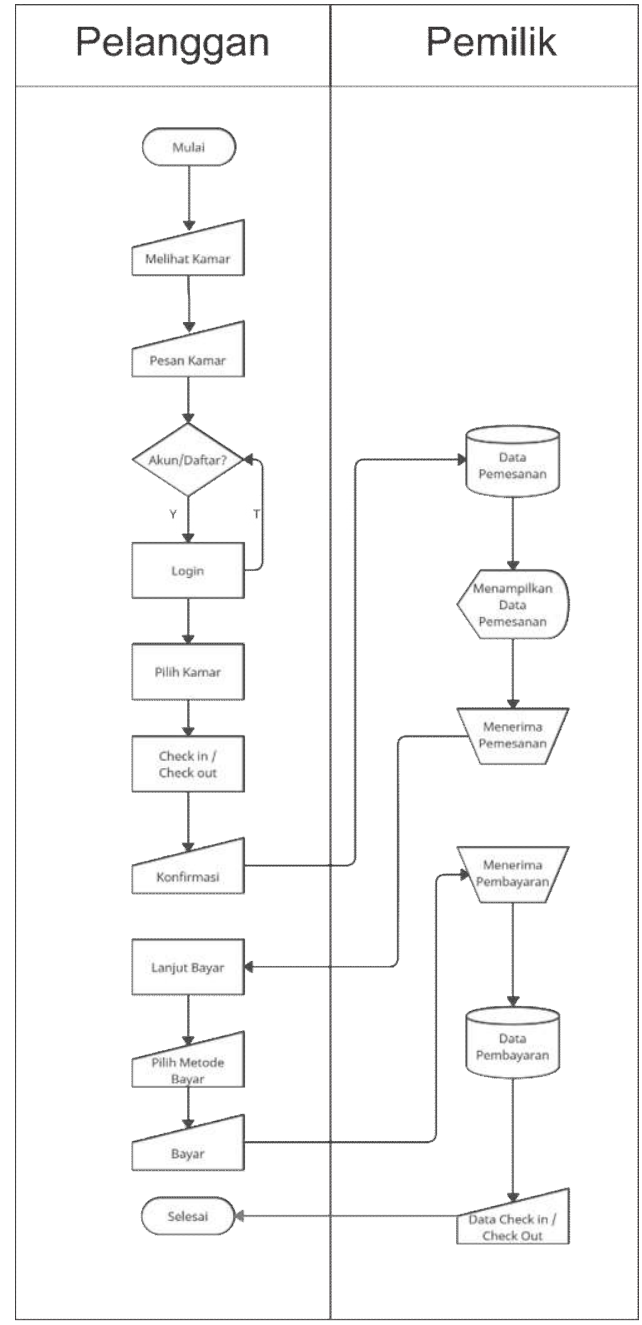

Gambar 1. Flowchart Sistem

Use case mendiskripsikan sebuah interaksi antara aktor dengan sistem yang dibuat. Yaitu Aplikasi Reservasi Penginapan akan dibahas dalam use case yaitu mengenai aksi antar aktor yang meliputi pelanggan dan pengelola penginapan.

a. Pelanggan adalah aktor yang melakukan proses reservasi melalui aplikasi.

b. Pengelola adalah aktor yang mengelola data pelanggan, data kamar, data pemesanan, dan data transaksi dari web admin.

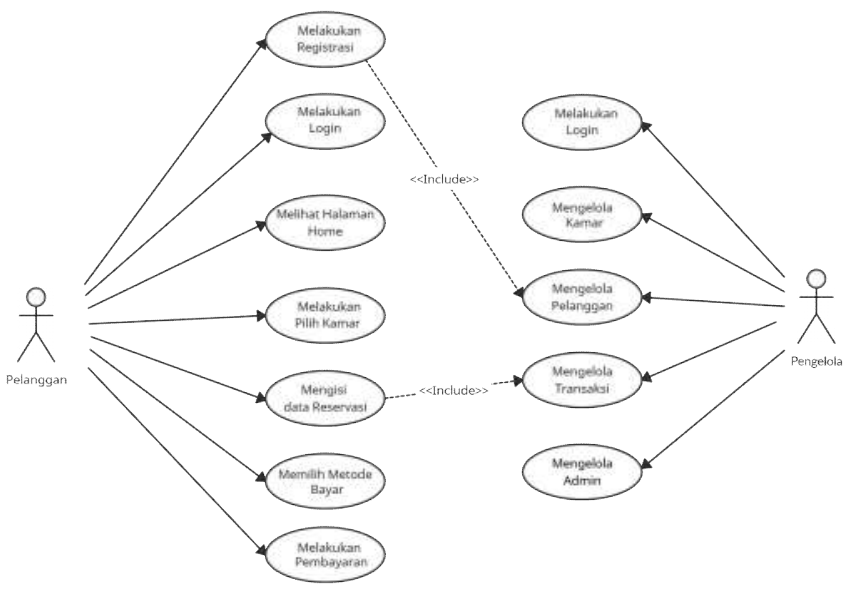

Gambar 2. UseCase Diagram 


\section{HASIL DAN PEMBAHASAN}

\subsection{Tampilan Implementasi Program}

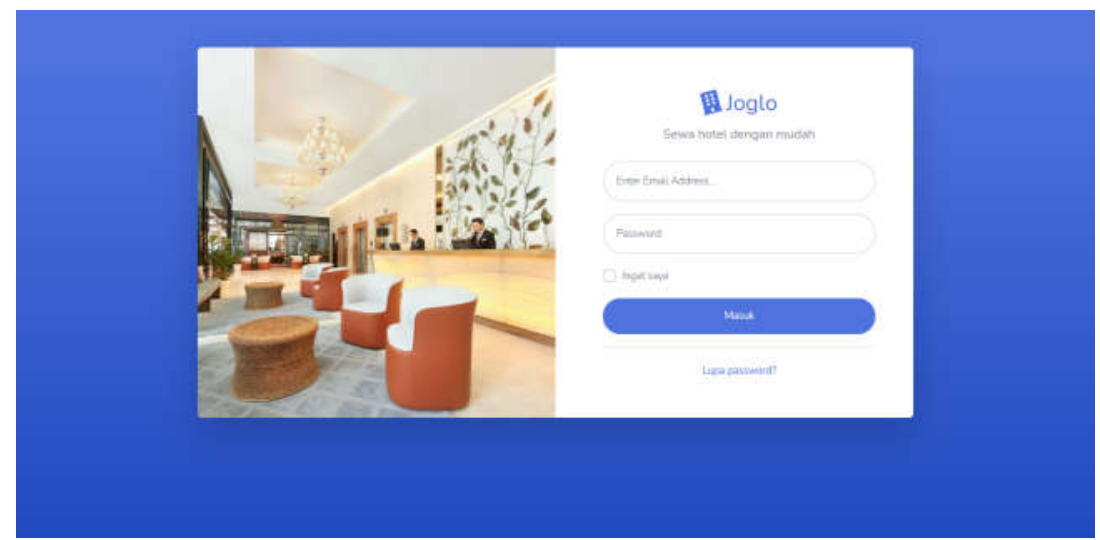

Gambar 3. Halaman Login admin

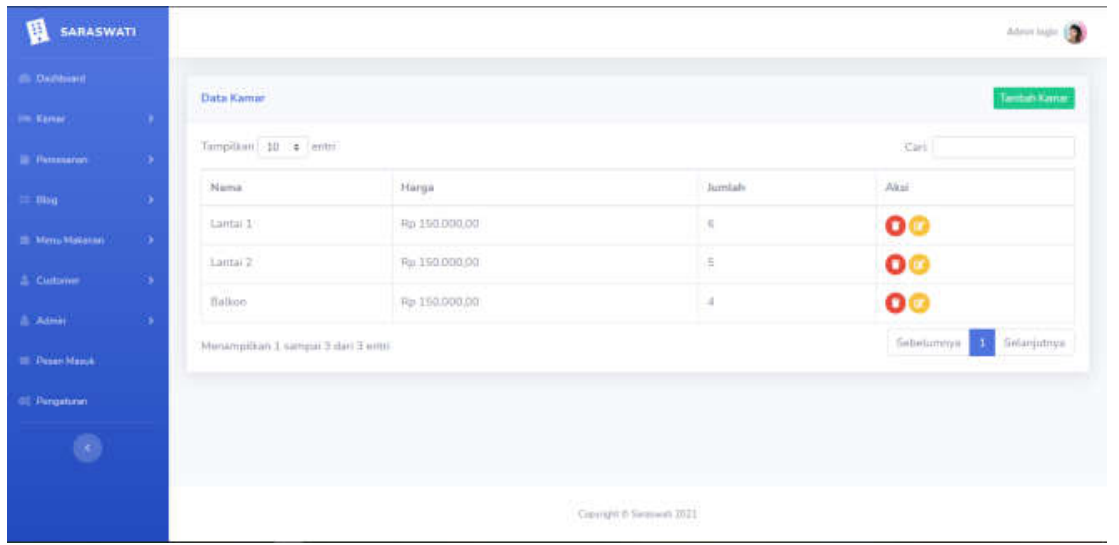

Gambar 4. Halaman Kamar

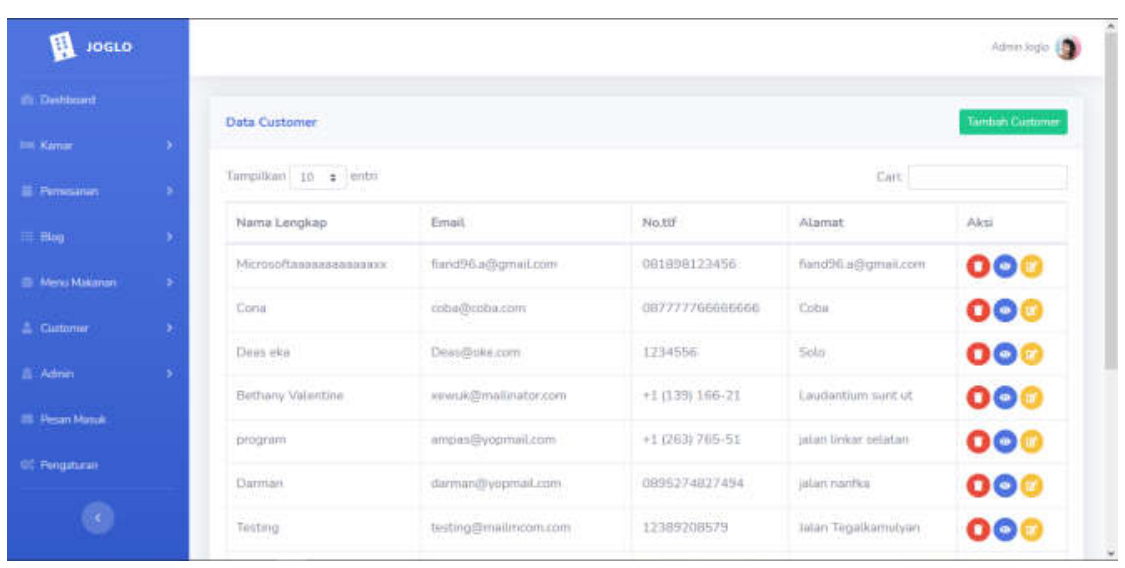

Gambar 5. Halaman Pelanggan 


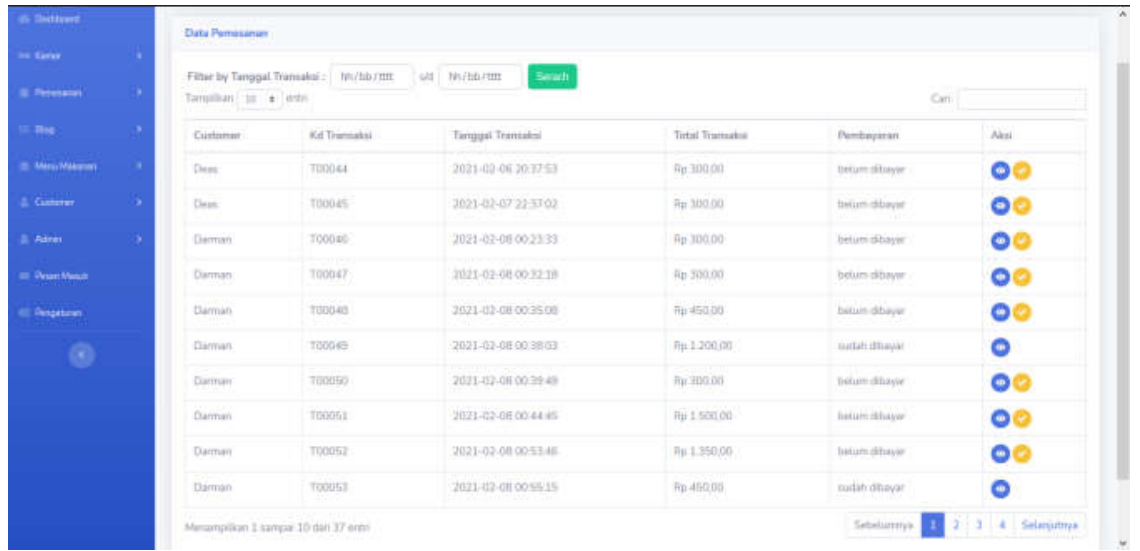

Gambar 6. Halaman Pemesanan

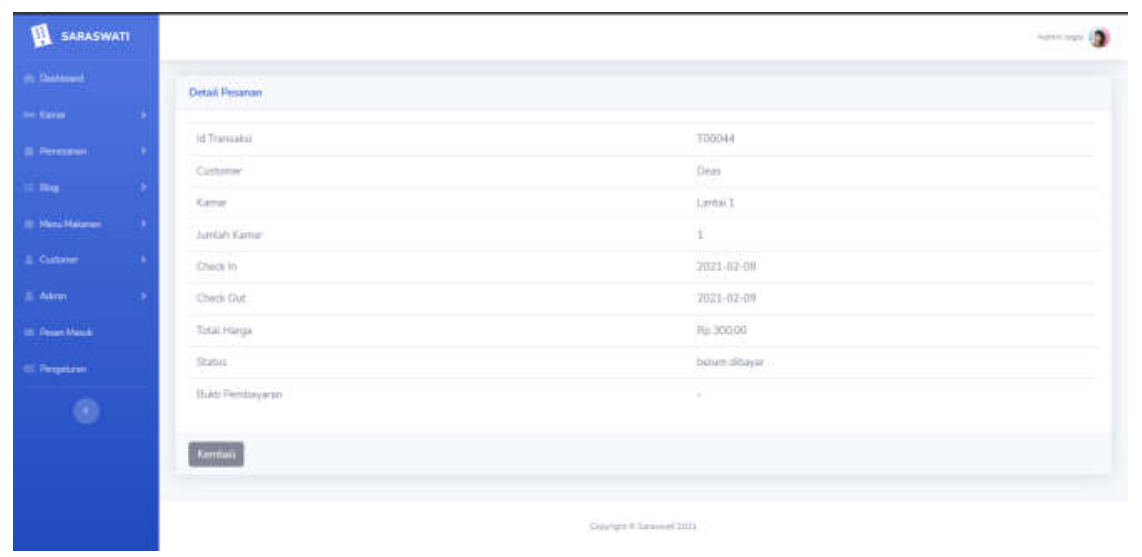

Gambar 7. Halaman Detail Pesanan

\subsection{Pemeliharaan Sistem}

Tahap pemeliharaan dilakukan setelah tahap implementasi. Sistem baru yang berjalan digunakan sesuai dengan keperluan organisasi. Selama masa hidupnya, sistem secara periodik akan ditinjau. Perubahan dilakukan jika muncul masalah atau jika ternyata ada kebutuhan baru. Selanjutnya, organisasi akan menggunakan sistem yang telah diperbaiki tersebut. Pemeliharaan sistem meliputi:

a. System Back-Up

Membuat Salinan/copy untuk data-data penting yang ada pada komputer admin maupun server kedalam backup storage.

b. System Optimization

Melakukan Defragmentasi data dan membuang sampah-sampah yang ada pada komputer, serta memperbaiki kesalahan setting sehingga komputer dapat berjalan normal.

c. System Rebuild

Membangun dan menata ulang kembali sistem yang rusak oleh faktor yang tidak disengaja, agar dapat bekerja normal kembali.

d. System Upgrade

Menambah fungsi, memperbaharui sistem yang ada sesuai dengan kebutuhan admin, serta melakukan testing stabilitas untuk hardware dan software.

e. Training dan Pelatihan

Memberikan pengarahan dan konsultasi kepada karyawan Black origin sehingga staff kasir dapat mengoperasikan komputer sesuai dengan prosedur pengoperasian komputer yang baik dan benar. 
f. Update Anti Virus dan Pembersihan Virus

Melakukan update definition file anti virus sehingga anti virus yang ada dapat memproteksi komputer dari serangan virus dan juga melakukan scanning virus serta membersihkan komputer dari virus.

g. System Security

Pemasangan firewall dan sistem authentifikasi untuk pengamanan sistem dan data penting sistem informasi di Black origin dari orang luar yang tidak berkepentingan.

Langkah-langkah pemeliharaan sistem terdiri dari:

a. Penggunaan Sistem

Menggunakan sistem yang sesuai dengan fungsi tugasnya masing-masing untuk operasi rutin atau sehari-hari

b. Audit Sistem

Melakukan penggunaan dan penelitian formal untuk menentukan seberapa baik sistem baru dapat memenuhi kriteria kinerja. Hal semacam ini disebut penelaahan setelah penerapan dan dapat dilakukan oleh seorang auditor internal.

c. Penjagaan Sistem

Melakukan pemantauan untuk pemerikasaan rutin sehingga sistem tetap beroperasi dengan baik. Selain itu juga untuk menjaga kemutakhiran sistem jika sewaktu-waktu terjadi perubahan lingkungan sistem atau modifikasi rancangan software.

d. Perbaikan Sistem

Melakukan perbaikan jika dalam operasi terjadi kesalahan (bugs) dalam program atau kelemahan rancangan yang tidak terdeteksi saat tahap pengujian sistem.

e. Peningkatan Sistem

Yaitu melakukan modifikasi terhadap sistem ketika terdapat potensi peningkatan sistem setelah sistem berjalan beberapa waktu.

\section{KESIMPULAN}

Proses perancangan Reservasi Penginapan Berbasis Android (Studi Kasus: Pondok Wisata Saraswati) yang telah dibuat dapat diambil kesimpulan antara lain didalam aplikasi terdapat berbagai fitur untuk mengetahui foto kamar, harga permalam, tanggal check in dan check out dan proses pembayaran menggunakan metode pembayaran yaitu payment gateway. Aplikasi Reservasi Penginapan Berbasis Android (Studi kasus: Pondok Wisata Saraswati) perancangan sistem menggunakan metode waterfall, sedangkan untuk Analisis kelemahan sistem menggunakan analisa PIECES serta pemodelan Flowchart dan UML (Unified Modeling Language) dengan komponen yang digunakan yaitu use case diagram, class diagram, activity diagram, sequence diagram, dan desain interface. Sistem dibangun menggunakan bahasa pemrograman JavaScript, HTML, PHP. Sistem dibangun dengan software Android Studio, android SDK, Visual Studio Code, XAMPP dan database menggunakan MySQL.

\section{SARAN}

Aplikasi Reservasi Penginapan berbasis Android (Studi Kasus: Pondok Wisata Saraswati) masih dapat dikembangkan lebih lanjut, dengan harapan pada aplikasi yang dikembangkan, menambahkan notifikasi ketika pengelola menambahkan Kategori kamar baru, terdapat promo harga, dan fasilitas penginapan lainnya. Pada aplikasi yang dikembangkan, Menambahkan fitur chat lewat aplikasi seperti Whatsapp, dan Line. Pada aplikasi yang dikembangkan, ditampilkan pengeluaran untuk pajak listrik, pajak bumi dan bangunan, pajak air dan pajak penghasilan. Pada aplikasi yang dikembangkan, menambah pengguna dari pihak pengelola penginapan yang lain. Sehingga pelanggan punya lebih banyak pilihan penginapan. 


\section{DAFTAR PUSTAKA}

[1] Aditya, Desta and , Nurgiyatna, ST., MSc., PhD. 2017. Sistem Reservasi Tempat Meeting Berbasis Android. Diploma thesis, Universitas Muhammadiyah Surakarta

[2] Al Fatta, Hanif. 2007. Analisis dan perancangan Sistem Informasi.Yogyakarta: Andi

[3] Aldair, Muhammad Ilham.2018. Pembuatan Aplikasi Reservasi Homestay menggunakan Algoritma K-Means berbasis Android.Jakarta:UIN Syarief Hdiyatullah

[4] Alfata, Hanif Al. 2007. Analisis dan Perancangan Sistem Informasi. Yogyakarta: Andi.

[5] Arief, M.Rudianto. 2011. Pemrograman Web Dinamis Menggunakan Php dan Mysql.Yogyakarta : Andi.

[6] Arthana, I. K. R. 2017. Modul Pengembangan Aplikasi Android Berbasis Client-Server Instalasi dan Konfigurasi Emulator Versi 1.0 Disajikan dalam mata kuliah Pemrograman Sistem Tersebar Jurusan Manajemen Informatika Universitas Pendidikan Ganesha Persiapan Pengembangan Aplikasi.

[7] Barakbah, Ali Ridho. 2013. Logika dan Algoritma Backpropagation. In PENS.

[8] Dr. Sandu Siyoto, SKM., M.Kes dan M.Ali Sodik, M.. 2015. Dasar Metodologi Penelitian Penulis. Literasi Media Publishing.

[9] Henderson, H. 2009. Encyclopedia of Computer Science and Technology.(RevisedEditionEdition). New York: Facts on File, Inc

[10] Jazi Eko Istiyanto. 2013. Pemrograman Smart Phone menggunakan SDK Android dan Hacking Android. Yogyakarta: Graha Ilmu.

[11] Kadir, Abdul .2009. Membuat Aplikasi Web dengan PHP+Database MySQL. Yogyakarta: Andi Offset

[12] Kotler diterjemahkan oleh Rony A.Rusli, H. 2000. Buku Manajemen Pemasaran.

[13] MADCOM. 2016. Pemrograman PHP dan MySQL Untuk Pemula. Yogyakarta: C.V Andi.

[14] Nugroho, Adi. 2006. E-commerce. Informatika Bandung. Bandung.

[15] Paralegal. 2020. Pengertian usaha besar. https://paralegal.id/pengertian/usaha-besar/ Diakses 20 Mei 2020

[16] Rosa AS dan M.Shalahuddin. 2014. Rekayasa Perangkat Lunak Terstruktur Dan Berorientasi Objek. Bandung: INFORMATIKA.

[17] Rosa AS, M. S. 2011. Modul Pembelajaran Rekayasa Perangkat Lunak : Terstruktur dan Beorientasi Objek. Bandung: Modula.

[18] Safaat, Nazrudi. 2012. Android Pemrograman Aplikasi Mobile Smartphone dan Tablet PC Berbasis Android.Bandung:Informastika.

[19] Salahudin, M., Rosa A. S. 2014. Rekayasa Perangkat Lunak Terstuktur dan berorientasi Objek.Bandung:Informatika.

[20] Siyoto, Sandu dan Ali Sodik.2015.Dasar Metodologi Penilitian.Yogyakarta:Literasi Media Publishing

[21] Suri Jamlean, Atika.2017.Rancang Bangun Aplikasi Reservasi Tempat Berbasis Web Pada PT. LAZIZA RAHMAT SEMESTA.Surabaya:STIKOM Surabaya

[22] Suwantoro, Gamal. 2004. Dasar-dasar Pariwisata. Penerbit Andi Yogyakarta

[23] Uli. (n.d.).2019. IGOS Training Tool Kit "RDBMS (Relational DataBase Management System): MySQL."

[24] Widanaputa, A.A.GP dkk. 2009 Akutansi Perhotelan pendekatan sistem informasi. Yogyakarta : Graha Ilmu

[25] Wolfson, Mike \& Felker, Donn. 2013. Android Developer Tools Essentials: Android Studio to Zipalign. O'Reilly Media, Inc 